\title{
HORMONAL EFFECTS ON HEALTH BIOMARKERS AND REPRODUCTIVE PERFORMANCE IN BUFFALOES (Bubalus bubalis) WITH LOW, MEDIUM AND HIGH MILK PRODUCTION
}

\author{
R. Shahid ${ }^{1}$, Z. I. Qureshi ${ }^{1}$ and Zia-ur-Rahman ${ }^{2}$ \\ ${ }^{1}$ Department of Theriogenology ${ }^{1}$, University of Agriculture, Faisalabad-38040, Pakistan \\ ${ }^{2}$ Institute of Pharmacy, Physiology and Pharmacology, University of Agriculture, Faisalabad-38040, Pakistan \\ "Corresponding Author's e-mail: rehmatdr@yahoo.com
}

\begin{abstract}
This study was conducted to determine the effects of Bovine somatotropin (rbST) and oxytocin on various health biomarkers, reproductive performance and milk composition of buffaloes during spring and hot summer. A total of 60 Nili-Ravi buffaloes were randomly divided into three groups based on their milk production. Low (1-2.9 liters/milking), medium (3-5.9 liters/milking) and High (6-12 liters/milking), with ( $\mathrm{n}=10)$ animals in each group during spring and summer. Animals of respective groups received recombinant bovine somatotropin (rbST) (Boostin-250 manufactured by LG Life Sciences, Ltd, South Korea and distributed by M/S Ghazi Brothers, Pakistan) 35mg on alternate days and oxytocin $10 \mathrm{IU}$ before each milking, starting on day 70 postpartum till the end of lactation. Blood samples were collected to determine Total oxidant status (TOS), Total antioxidant capacity (TAC), Serum alanine aminotransferase (ALT) and Aspartate aminotransferase (AST). Milk samples were analyzed for fat, protein, lactose and SNF contents. Reproductive performance parameters were assessed by rectal palpation and from farm record. Results revealed that mean ALT, AST and TOS activity was significantly higher during summer. Milk production was very well correlated with their assigned groups of milk production during spring. Milk fat, protein and lactose contents decreased due to rbST, oxytocin or rbST+ oxytocin treatment. In conclusion during summer, milk yield was increased after rbST+ oxytocin treatment, but decreased following treatment with either hormone.
\end{abstract}

Key words: milk production and composition, Somatotropin, Oxytocin, Nili-Ravi buffaloes, Seasons

https://doi.org/10.36899/JAPS.2021.4.0291 Published online December 15, 2020

\section{INTRODUCTION}

In Pakistan, the livestock sector accounts for approximately $56.3 \%$ of the agriculture value added and $11.8 \%$ of GDP. Approximately $35-40$ million of the rural population is dependent directly or indirectly on livestock. Buffalo is the major source of milk production in the country. Nili-Ravi is the best milk breed of buffalo with an average milk yield of 2000L/lactation (Agarwal and Tomar, 1998). Buffalo milk is liked by the population masses due to its richness, taste and flavor. Buffaloes also provide beef, hides, traction and tilling power for various farm operations. Milk production is apparently the greatest component of economic change of the lower strata of the farming community, while income from the sale of milk constituted about 25 per cent of the total farm income in Punjab. This income also compensates for the negative income balance from general farming, particularly for marginal and small farmers. About 98 per cent of buffaloes in the region are raised by small farmers owning less than two hectares of land, with less than five buffaloes per house hold (Anonymous, 2014-15).

There are approximately 35.6 million head of buffaloes in Pakistan, producing thousand tons of milk annually for human consumption (Anonymous, 2014- 15).
In spite of this large number, per animal productivity is low compared with most of the exotic dairy cattle breeds. The average milk yield per animal is 7-8 liter/day at farm level, which needs to be increased to make this animal more profitable, as well as to meet the protein requirements of the ever-increasing human population in the country.

Bovine Somatotropin (bST) is a polypeptide hormone produced by the somatotrophs of the anterior pituitary gland and consists of a chain of 190 to 191 amino acids. This hormone induces marked changes in nutrient partitioning in target tissues and stimulates cell proliferation mediated by insulin-like growth factor (IGFI). In 1982, recombinant bovine somatotropin (rbST) was produced by recombinant DNA technology that permitted scientists around the world to observe various aspects of its biology. In this technique, the genes that produce somatotropin were identified in bovine tissues and inserted as a part of plasmid into specific bacteria. With bacterial replication, the new genes were also replicated and conceded along to all new bacteria. Purified rbST was extracted from these freshly grown bacteria (Bauman, 1992). The commercial formula of rbST (Posilac) is leucine variant-127, having an extra methionine at the $\mathrm{NH} 2$ terminus. 
Low milk production, with lack of persistency, is the major problem for small dairy farmers in Pakistan. Breeding and selection have failed to increase the amount of milk produced in buffaloes as it did in cows. The application of newly emerging biotechnologies, like recombinant bovine somatotropin (rbST) supported with appropriate nutrition and herd management, can be an alternate option for achieving the goal of high milk production in buffaloes. It has been reported that rbST is a production- enhancing technology that allows the dairy industry to produce milk more efficiently. This means that each liter of milk produced by cows treated with rbST requires fewer feed nutrients, results in less animal waste, and has a reduced carbon footprint, compared with each liter of milk produced by cows that are not treated with rbST (Capper et al., 2008). Recombinant bovine somatotropin hormone (rbST) is one of the biotechnological products that increase the milk production per unit of feed intake. Typically, milk yield increases up to $10-15 \%$ through the use of rbST (NRC, 1994). Ludri et al. (1989) reported that administration of rbST resulted in improvement of $12-25 \%$ in milk yield without any substantial alteration in the composition of milk.

Oxytocin is a polypeptide hormone synthesized in the supraoptic and paraventricular nuclei of the hypothalamus and stored in the posterior pituitary gland, from where it is released in response to neuroendocrine reflexes. Oxytocin stimulates uterine smooth muscle contractions during parturition and mammary gland muscles during milk ejection. In addition, its receptors are present in the oviduct, and the hormone is released during mating of female goats. It also effects the blood pressure (Ayad et al. 1990). It is believed that oxytocin has some effects on the central nervous system such as memory, learning capability, nursing, sexual and feeding behavior (Argiolas and Gessa, 1991). It is also involved in the luteolytic mechanism in cows.

In Pakistan at present, rbST is commonly used to increase milk production in dairy animals, while oxytocin is also used for milk letdown in cattle and buffaloes. The present study was designed as there is little information available in the literature regarding the effects of rbST and oxytocin on health indicators, reproductive performance and milk composition of Nili-Ravi buffaloes (Bubalus bubalis) during spring and summer seasons.

\section{MATERIALS AND METHODS}

The present study was performed in 2015 , at a private (S. B. dairy farm) in Faisalabad. The laboratory work was completed in the Department of Physiology and Pharmacology, University of Agriculture, Faisalabad.

Experimental animals and treatments: In this study, a total of 60 multiparous milking buffaloes in their 2 nd or 3rd lactation and maintained under same management and housing conditions were divided randomly into three groups, based on their milk production, i.e low (1-2.9 liters/milking), medium (3-5.9 liters/milking) and high (612 liters/milking), with ( $\mathrm{n}=10)$ buffaloes in each group during spring and summer. The rbST (Boostin-250 ${ }^{\mathrm{TM}}$ manufactured by LG Life Sciences, Ltd, South Korea and distributed by M/S Ghazi Brothers, Pakistan) was injected at $35 \mathrm{mg}$ on alternate days by s/c route at croup region, while oxytocin was used at the dose rate of $1 \mathrm{ml}$ (10 I.U), $\mathrm{I} / \mathrm{m}$ before each milking. The treatments were started on day 70 postpartum and continued till the end of lactation.

About $10 \mathrm{ml}$ blood samples were collected once in the middle of each season from each animal in a sterilized test tube, serum was separated and stored at $20^{\circ} \mathrm{C}$ for further analysis. Similarly, about $100 \mathrm{ml}$ milk was collected from each animal of all groups during each season. These milk samples were stored at $-20^{\circ} \mathrm{C}$. Serum samples collected from animals were analyzed for Total Oxidant Status (TOS) and Total Antioxidant Capacity (TAC) were determined using the protocol of Erel (2005) and Erel (2004), respectively. Activities of Alanine Aminotransferase (ALT) and Aspartate Aminotransferase (AST) enzymes were determined using commercially available kits (Randox Lab. Ltd. UK). Reproductive performance parameters including, calving to estrus interval, service period and calving interval were recorded. Reproductive disorders including endometritis and vaginal prolapse were recorded. Ovarian activity like, cyclic and non-cyclic ovaries was observed by rectal palpation. Milk samples were analyzed for fat, protein, lactose and solidnot-fat (SNF) contents. Milk fat and protein contents were determined by the procedure described by David (1977). Milk lactose contents were estimated by using Fehling's solution titration method, as described by Egan et al. (1981) and SNF was determined by Fleischman formula. Data collected on various parameters were tabulated to show means and standard error of mean for group. Analysis of variance was applied to extract the difference between and within groups. Duncan multiple range test was applied for multiple means comparison, where necessary. However, Pearson's Chi square test was used for the statistical analysis of data in percentage.

\section{RESULTS AND DISCUSSION}

Health biomarkers: Differences in serum ALT and AST activity due to milk production potential, two seasons, as well as their interaction were non-significant. Overall mean ALT activity was lower during spring as compared to summer. However, mean serum AST activity was significantly $(\mathrm{P} \leq 0.05)$ higher during summer than in spring (Table I). Mean serum TOS showed significant $(\mathrm{P} \leq 0.01)$ difference between spring and summer seasons. However, difference due to milk production potentials of animals and interaction between season $\times$ milk productions was non- 
significant. Overall mean serum TOS of buffaloes was significantly higher during summer than in spring (Table I). Serum TAC did not reveal any significant difference, while variation due to seasonal effect was significant $(\mathrm{P} \leq 0.01)$. Overall serum TAC was significantly higher during spring as compared to summer season (Table 1).

Liver functions in relation to milk production potential of dairy buffaloes treated with rbST and oxytocin were measured in terms of ALT and AST activities, TOS and TAC. Buffaloes with low, medium and high milk production did not show any difference in serum ALT and AST levels, and TOS and TAC values following treatment with rbST. These results of the milk production potential groups are similar to those of Chaiyabutr et al., (2011), who used three injections of rbST (500 mg per dose) at early, mid and late stages of lactation in cooled and noncooled cows and found that the activities of plasma AST and ALT were not affected by rbST supplementation. It is generally observed that milk yield of cows usually varies at early, mid and late stages of lactations (Fontes et al., 1997). Similarly, Abdel-Rahman et al., (2010) reported that the levels of AST and ALT revealed non-significant changes in cows when given 250 and $500 \mathrm{mg}$ of rbST after every 15 days for 5 months. These results indicate that buffaloes were not under any stress due to rbST and/or oxytocin treatments during study period; they were in good health and were producing milk according to their potential.

Reproductive performance: During spring season, $53.3 \%(\mathrm{n}=8)$ buffaloes in low, $46.6 \%(\mathrm{n}=7)$ in medium and $6.6 \%(\mathrm{n}=1)$ in high milk yielding group were cyclic based on ovarian status. The buffaloes $(60.0 \% ; n=9)$ were pregnant in high milk production potential group, followed by low $(46.6 \% ; n=7)$ and lowest was seen in medium group $(33.3 \%$; $n=5)$. (Table II). During summer ovarian status determined by rectal examination showed that in low milk producing buffaloes, $50.0 \%(\mathrm{n}=5)$ were cyclic in contrast to medium milk producer that showed $30.0 \%$ $(\mathrm{n}=3)$ were cyclic. In high milk producing buffaloes, there was $10.0 \%(n=1)$ were cyclic, However, these differences were not statistically significant (Table II). Reproductive status of buffaloes showed that $40.0 \%(n=4)$ buffaloes were pregnant in low milk yield group as compared to medium which showed $10.0 \%(\mathrm{n}=1)$ pregnant. In high milk producing group $20.0 \% \quad(n=2)$ buffaloes were pregnant. These differences were not significant in present study during summer. Endometritis was found to be present in $30.0 \%(\mathrm{n}=3)$ in low yielding as compared to medium milk yielding animals $(10.0 \% ; \mathrm{n}=1)$ and in high yielding animals $(20.0 \% ; n=2)$, statistically the differences were non-significant.

The incidence of endometritis was not affected significantly in buffaloes of low, medium and high milk yield. These results are supported by those of Silvia et al., (2002). Gohary et al., (2014) reported that incidence of endometritis was not different between groups when monitored after 42 days of first treatment of rbST. In the present study, the incidence of endometritis in various groups ranged from 3.44 to $37.5 \%$. Previous studies based on clinical data have shown the prevalence of endometritis in buffaloes from $16.73 \%$ to $42 \%$ (Hanafi et al., 2008). However, it does not seem to be possible to relate hormone treatments to animal's health status under field condition, as a wide range of environment as well as management can influence the results.

The frequency of cyclic animals of three milk yield groups given rbST and oxytocin was not affected significantly. Previous studies have shown the presence of somatotropin receptors in the granulosa cells of Graafian follicles (Lucy, 2000). It was expected that rbST treatment would stimulate follicular development and increase in number of cyclic animals. Lucy (2000) reported that rbST treatment to lactating cows increased the blood concentration of ST and IGF-1.

Milk composition: Difference in milk fat and protein contents of buffaloes did not show any significant difference. Overall mean milk fat contents were nonsignificantly higher during spring (Table III). Overall mean milk protein and lactose was significantly $(\mathrm{P} \leq 0.01)$ higher in animals treated with rbST and oxytocin during spring as compared to summer (Table III). Mean milk lactose in high milk production animals' contents was significantly higher compared to in low and medium milk production potential buffaloes. However, the difference between later two groups was non-significant. Difference in milk SNF was non-significant due to seasons, but it was significant due to milk production potential and season $\times$ milk production potential interaction. Overall mean milk SNF contents of buffaloes of low and medium milk production groups were almost similar; however, these values were significantly $(\mathrm{P} \leq 0.01)$ lower from high milk producing buffaloes. Overall mean SNF values were almost similar during spring and summer seasons (Table III).

In high milk production potential animals milk lactose and SNF contents were significantly $(\mathrm{P} \leq 0.01)$ higher than low and medium milk production groups. Milk fat and proteins contents were not different among three milk production groups. Eisenbesz et al., (1990) reported no change in percentage of fat, proteins and total solids in milk of dairy cows injected with somatotropin. Eppard et al., (1987) reported that as the dose of rbST increased the fat percentage in milk increased, however, milk protein percent declined. In another study reported 
Table 1. Mean values $( \pm$ SE) for the effect of seasons and milk production potential groups on serum ALT, AST, TOS and TAC of buffaloes treated with rbST and oxytocinj.

\begin{tabular}{|c|c|c|c|c|c|c|c|c|c|c|c|c|}
\hline \multirow[b]{2}{*}{$\begin{array}{c}\text { Milk } \\
\text { Production } \\
\text { Groups }\end{array}$} & \multicolumn{3}{|c|}{$\operatorname{ALT}(\mathbf{U} / \mathbf{L})$} & \multicolumn{3}{|c|}{$\operatorname{AST}(\mathrm{U} / \mathbf{L})$} & \multicolumn{3}{|c|}{ TOS ( $\mu$ moI H2O2 eqiiv. L-1) } & \multicolumn{3}{|c|}{$\begin{array}{c}\text { TAC (mmol Trolox } \\
\text { equivalent/L) }\end{array}$} \\
\hline & Spring & Summer & $\begin{array}{c}\text { Overall } \\
\text { Mean }\end{array}$ & Spring & Summer & $\begin{array}{c}\text { Overall } \\
\text { Mean }\end{array}$ & Spring & Summer & $\begin{array}{c}\text { Overall } \\
\text { Mean }\end{array}$ & Spring & Summer & $\begin{array}{c}\text { Overall } \\
\text { Mean }\end{array}$ \\
\hline \multirow{2}{*}{$\begin{array}{l}\text { Low } \\
\text { Medium }\end{array}$} & $10.85 \pm 0.93$ & $12.80 \pm 1.91$ & $11.63 \pm 0.94$ & $9.47 \pm 1.42$ & $16.14 \pm 1.86$ & $12.14 \pm 1.29$ & $0.237 \pm 0.010$ & $0.337 \pm 0.009$ & $0.277 \pm 0.012$ & $0.85 \pm 0.04$ & $0.60 \pm 0.06$ & \multirow{2}{*}{$\begin{array}{l}0.70 \pm 0.04 \\
0.66 \pm 0.04\end{array}$} \\
\hline & $9.10 \pm 1.13$ & $11.90 \pm 0.62$ & $10.22 \pm 0.76$ & $13.16 \pm 2.06$ & $18.37 \pm 3.08$ & $15.24 \pm 1.78$ & $0.258 \pm 0.011$ & & & & & \\
\hline \multirow{2}{*}{$\begin{array}{l}\text { High } \\
\text { Overall } \\
\text { Means }\end{array}$} & $12.31 \pm 2.06$ & $13.45 \pm 0.73$ & $12.77 \pm 1.26$ & $14.40 \pm 2.28$ & $15.30 \pm 1.99$ & $14.76 \pm 1.56$ & $0.253 \pm 0.026$ & $0.322 \pm 0.007$ & $0.281 \pm 0.017$ & $0.81 \pm 0.03$ & $0.42 \pm 0.03$ & $0.57 \pm 0.05$ \\
\hline & $10.75 \pm 0.85$ & $12.72 \pm 0.70$ & & \multicolumn{3}{|c|}{$12.34 \pm 1.15^{\mathrm{B}} 16.60 \pm 1.34_{\mathrm{A}}$} & \multicolumn{3}{|c|}{$0.250 \pm 0.010_{\mathrm{B}} 0.327 \pm 0.005_{\mathrm{A}}$} & \multicolumn{3}{|c|}{$0.82 \pm 0.02_{\mathrm{A}} 0.53 \pm 0.03_{\mathrm{B}}$} \\
\hline
\end{tabular}

B: Values with different alphabets in a row differ significantly from each other $(\mathrm{P} \leq 0.05)$

Table 2. Data on reproductive performance in buffaloes of different milk production groups $(\mathrm{n}=15)$ in each group during spring and summer.

\begin{tabular}{|c|c|c|c|c|c|c|}
\hline \multirow{2}{*}{$\begin{array}{l}\text { Milk Production } \\
\text { Groups }\end{array}$} & \multicolumn{3}{|c|}{ Spring } & \multicolumn{3}{|c|}{ Summer } \\
\hline & $\begin{array}{c}\text { Animals with cyclic } \\
\text { ovary }\end{array}$ & $\begin{array}{c}\text { Pregnant } \\
\text { animals }\end{array}$ & $\begin{array}{c}\text { Animals with } \\
\text { endometritis }\end{array}$ & $\begin{array}{c}\text { Animals with cyclic } \\
\text { ovary }\end{array}$ & $\begin{array}{l}\text { Pregnant } \\
\text { animals }\end{array}$ & $\begin{array}{l}\text { Animals with } \\
\text { endometritis }\end{array}$ \\
\hline Low & $8(53.3 \%)$ & $7(46.6 \%)$ & $10(66.6 \%)$ & $5(50.0 \%)$ & $4(40.0 \%)$ & $3(30.0 \%)$ \\
\hline Medium & $7(46.6 \%)$ & $5(33.3 \%)$ & $4(26.6 \%)$ & $3(30.0 \%)$ & $1(10.0 \%)$ & $1(10.0 \%)$ \\
\hline High & $1(9.1 \%)$ & $9(60.0 \%)$ & $4(26.6 \%)$ & $1(10.0 \%)$ & $2(20.0 \%)$ & $4(40.0 \%)$ \\
\hline Chi-square value & $6.841 \mathrm{NS}$ & $3.943 \mathrm{NS}$ & $0.728 \mathrm{NS}$ & $2.983 \mathrm{NS}$ & $2.456 \mathrm{NS}$ & $0.711 \mathrm{NS}$ \\
\hline
\end{tabular}

Values with parentheses are percentages; NS $=$ Non-significant.

Table 3. Mean values $( \pm \mathrm{SE})$ of milk fat, protein, lactose and solids-not-fat $(\%)$ contents for different seasons and different milk production potentials of buffaloes treated with rbST and oxytocin.

\begin{tabular}{|c|c|c|c|c|c|c|c|c|c|c|c|c|}
\hline \multirow{2}{*}{$\begin{array}{c}\text { Milk } \\
\text { Production } \\
\text { groups } \\
\end{array}$} & \multicolumn{3}{|c|}{ Fat $(\%)$} & \multicolumn{3}{|c|}{ Protein (\%) } & \multicolumn{3}{|c|}{ Lactose (\%) } & \multicolumn{3}{|c|}{ Solids-not-fat (\%) } \\
\hline & Spring & Summer & $\begin{array}{c}\text { Overall } \\
\text { means }\end{array}$ & Spring & Summer & $\begin{array}{c}\text { Overall } \\
\text { means }\end{array}$ & Spring & Summer & $\begin{array}{c}\text { Overall } \\
\text { means }\end{array}$ & Spring & Summer & $\begin{array}{c}\text { Overall } \\
\text { means }\end{array}$ \\
\hline Low & $6.27 \pm 0.49$ & $5.96 \pm 0.36$ & $6.12 \pm 0.30$ & $8.54 \pm 0.96$ & $4.11 \pm 0.31$ & $6.33 \pm 0.71$ & $6.49 \pm 0.22_{\mathrm{d}}$ & $7.00 \pm 0.37_{\mathrm{c}}$ & $6.75 \pm 0.22_{B}$ & $7.75 \pm 0.20_{\mathrm{c}}$ & $7.69 \pm 0.23_{\mathrm{c}}$ & $7.72 \pm 0.15_{\mathrm{B}}$ \\
\hline Medium & $5.65 \pm 0.41$ & $5.35 \pm 0.33$ & $5.50 \pm 0.26$ & $6.71 \pm 0.54$ & $4.33 \pm 0.51$ & $5.52 \pm 0.45$ & $8.08 \pm 1.03_{b}$ & $5.44 \pm 0.29_{\mathrm{e}}$ & $6.76 \pm 0.60_{\mathrm{B}}$ & $8.20 \pm 0.29 b$ & $7.61 \pm 0.22_{\mathrm{d}}$ & $7.90 \pm 0.19_{\mathrm{B}}$ \\
\hline High & $6.07 \pm 0.35$ & $6.13 \pm 0.14$ & $6.10 \pm 0.18$ & $6.39 \pm 0.34$ & $4.19 \pm 0.21$ & $5.29 \pm 0.32$ & $13.46 \pm 1.01_{\mathrm{a}}$ & $6.66 \pm 0.19_{\mathrm{d}}$ & $10.06 \pm 0.93_{\mathrm{A}}$ & $8.04 \pm 0.30_{\mathrm{b}}$ & $9.00 \pm 0.14 \mathrm{a}$ & $8.52 \pm 0.19_{\mathrm{A}}$ \\
\hline $\begin{array}{l}\text { Overall } \\
\text { Means }\end{array}$ & $6.00 \pm 0.24$ & $5.81 \pm 0.17$ & & $7.21 \pm 0.41_{\mathrm{A}}$ & $4.21 \pm 0.20_{\mathrm{B}}$ & & $9.34 \pm 0.73_{\mathrm{A}}$ & $6.37 \pm 0.20_{\mathrm{B}}$ & & $8.00 \pm 0.15$ & $8.10 \pm 0.16$ & \\
\hline
\end{tabular}

abcde: Values with different alphabets differ significantly from one another $(\mathrm{P} \leq 0.01)$.

$\mathrm{AB}$ : Values with different alphabets in a row differ significantly from one another $(\mathrm{P} \leq 0.01)$. 
by Helal and Lasheen (2008) showed that fat, total solids and total protein contents of milk did not change by treatment of rbST, however, milk lactose content was increased by $\mathrm{rbST}$ injection. Injection of bovine somatotropin to cattle has been reported to cause an increase in the relative amount of large chain fatty acids (Vandenberg, 1991). Bauman (1992) reported that rbST did not change the milk composition when animals were fed diet balanced in energy as well as proteins. Milk composition is variable normally because it depends upon the genetic makeup of animal, stage of lactation, diet composition as well as seasons. Milk fat and protein contents increased significantly during spring indicating a reduction in oxidation of amino acid as well as mobilization of labile protein reserves. Chalupa et al., (1996) demonstrated that when high producing animals are fed diet which is not deficient in protein or energy, they may respond to $\mathrm{rbST}$ treatment in increased milk proteins and fat contents.

\section{REFERENCES}

Abdel-Rahman, H.A., A.S. Khalil, H.T. EL-Hamamsy and O.H. Ezzo (2010). The effect of recombinant bovine somatotropin administration on milk production, some hemato-biochemical parameters and reproductive performance of lactating cows. Global Vet. 4: 366-373.

Agarwal, S.K. and O.S. Tomar, 1998. Reproductive Technologies in Buffaloes. Indian Veterinary Research Institute, Izatnagar, India.

Anonymous, 2014-15. Economic Survey of Pakistan, Finance Division, Economic Advisor's Wing, Govt. Pakistan, Islamabad.

Argiolas, A. and G. L. Gessa, 1991. Central function of oxytocin. Neurosci. Bio. beha. Rev., 15: $217-$ 231.

Ayad, V. J., S. A. McGoff, D.C. Wathes, 1990. Oxytocin receptors in the oviduct during the oestrous cycle of the ewe. J. of Endoc. 124:353-359.

Bauman, D.E. 1992. Bovine somatotropin: review of an emerging animal technology. J. Dairy Sci. 75: 3432-3451.

Capper, J.L., E. Castañeda-Gutiérrez and R.A. Cady, 2008. The environmental impact of recombinant bovine somatotropin (rbST) use in dairy production. Proc. Nat. Acad. Sci. USA. 105: 9668-9673.

Chaiyabutr, N., D. Boonsanit and S. Chanpongsang (2011). Effects of cooling and exogenous bovine somatotropin on hematological and biochemical parameters at different stages of lactation of crossbred Holstein Friesian cows in the tropics. Asian-Aust. J. Anim. Sci. 24(2): 230-238.

Chalupa, W., B. Vecchiarelli, D.T. Galligan, J.D. Verguson, L.S. Baird, R.W. Hemken, R.J.
Harmon, C.G. Soderholm, D.E. Otterby, R.J. Annexstad, J.G.Linn, W.P. Hansen, F.R. Ehle, D.L. Palmquist and R.G. Eggert (1996). Responses of dairy cows supplemented with somatotropin during weeks 5 through 43 of lactation. J. Dairy Sci. 79(5): 800-812.

David, C.L. (1977). Laboratory Guide in Dairy Chemistry Practical. FAO Regional Dairy Development and Training Centre for Asia and the Pacific, Dairy Training and Research Institute, Los Banos College, Languna, University of Philippine, Philippine.

Egan, H., R. Kirk and R. Sawyer (1981). Person's Chemical Analysis of Food. Churchill Livingstone, New York, USA.

Eisenbesz, W.A., D.J. Schingoethe, D.P Casper, R.D. Shaver and R.M. Cleale (1990). Lactational evaluation of recombinant of bovine somatotropin with corn and barley diets. J. Dairy Sci. 73(5): 1269-1279.

Eppard, P.J., D.E. Bauman, C.R. Curtis, H.N. Erb, G.M. Lanz and M.J. DeGeeter (1987). Effect of 188day treatment with somatotropin on health and reproductive performance of lactating dairy cows. J. Dairy Sci. 70(3): 582-591.

Erel, O. (2004). A novel automated direct measurement method for total antioxidant capacity using new generation, more stable ABTS radical cation. Clin. Biochem. 37(4): 277-285.

Erel, O. (2005). A new automated colorimetric method for measuring Total Oxidant Status. Clin. Biochem. 38(12): 1103-1111.

Fontes, Jr., V.K. Meserole, W. Mattos, R.P. Barros, Z. Wu and J.T. Huber (1997). Response of Brazilian crossbred cows to varying doses of bovine somatotropin. J. Dairy Sci. 80(12): 3234-3240.

Gohary, K., S.J. LeBlanc, K.D. Lissemore, M.W. Overton, M.W. Massow and T. F. Duffield (2014). Effect of prepartum administration of recombinant bovine somatotropin on health and performance of lactating dairy cows. J. Dairy Sci. 97(10): 6231-6241.

Hanafi, E.M., W.M. Ahmad, S.I. Abd El Moez, H.H. EL Khadrawy and A.R. Abd El Hameed (2008). Effect of clinical endometritis on ovarian activity and oxidative stress status in Egyptian Buffalocows. American-Eurasian J. Agric. \& Environ. Sci. 4(5): 530-536.

Helal, F.I.S and M.A. Lasheen (2008). The productive performance of Egyptian dairy buffaloes receiving biosynthetic bovine somatotropin (rbST) with or without Monensin. AmericanEurasian J. Agric. Environ. Sci., 3: 771-777.

Lucy, M.C. (2000). Regulation of Ovarian Follicular Growth by Somatotropin and insulin- like 
Growth Factors in Cattle. J. Dairy Sci. 83(7):1635-1647.

Ludri, R.S., R.C. Upadhyay, M. Singh, J.R.M. Guneratne and R.P. Basson. (1989). Milk production in lactating buffalo receiving recombinantly produced bovine somatotropin. J. Dairy Sci. 72(9): 2283-2287.
Silvia, W.J., R.W. Hemken and T.B. Hatler (2002). Timing of onset of somatotropin supplementation on reproductive performance in dairy cows. $\mathrm{J}$. Dairy Sci. 85(2): 384-389.

Vandenberg, G., (1991). A review of quality and processing suitability of milk from cows treated with bovine somatotropin. J. Dairy Sci. 74(2): 211. 